\title{
Kaempferol enhances cisplatin's effect on ovarian cancer cells through promoting apoptosis caused by down regulation of $\mathrm{cMyc}$
}

\author{
Haitao Luo ${ }^{1}$, Matthew K Daddysman'1, Gary O Rankin³, Bing-Hua Jiang² and Yi C Chen*1
}

\begin{abstract}
Background: Ovarian cancer is one of the most significant malignancies in the western world. Studies showed that Ovarian cancers tend to grow resistance to cisplatin treatment. Therefore, new approaches are needed in ovarian cancer treatment. Kaempferol is a dietary flavonoid that is widely distributed in fruits and vegetables, and epidemiology studies have revealed a protective effect of kaempferol against ovarian cancer risk. Our early studies also found that kaempferol is effective in reducing vascular endothelial growth factor (VEGF) expression in ovarian cancer cells. In this study, we investigated kaempferol's effects on sensitizing ovarian cancer cell growth in response to cisplatin treatment.

Results: Ten chemicals were screened for sensitizing OVCAR-3 ovarian cancer cell growth in response to cisplatin treatment. For kaempferol, which shows a significant synergistic interaction with cisplatin, expression of ABCC1, ABCC5, ABCC6, NFkB1, cMyc, and CDKN1A genes was further examined. For cisplatin/kaempferol treatments on OVCAR-3 cancer cells, the mRNA levels of ABCC1, ABCC5, and NFkB1 did not change. However, significant inhibition of ABCC6 and cMyc mRNA levels was observed for the cisplatin/kaempferol combined treatment. The CDKN1A mRNA levels were significantly up-regulated by cisplatin/kaempferol treatment. A plot of CDKN1 A mRNA levels against that of cMyc gene further revealed a reverse, linear relationship, proving CMyc's regulation on CDKN1A gene expressions. Our work found that kaempferol works synergistically with cisplatin in inhibiting ovarian cancer cell viability, and their inhibition on cell viabilities was induced through inhibiting ABCC 6 and $\mathrm{CMyc} \mathrm{gene} \mathrm{transcription.} \mathrm{Apoptosis} \mathrm{assay} \mathrm{showed} \mathrm{the}$ addition of $20 \mu \mathrm{M}$ kaempferol to the cisplatin treatment induces the apoptosis of the cancer cells.
\end{abstract}

Conclusions: Kaempferol enhances the effect of cisplatin through down regulation of cMyc in promoting apoptosis of ovarian cancer cells. As a dietary component, kaempferol sensitizes ovarian cancer cells to cisplatin treatment and deserves further studies for possible applications in chemotherapy of ovarian cancers.

\section{Background}

Ovarian cancer is one of the most important diseases for women in Western countries. It is the fifth leading cause of cancer-related deaths [1]. Treatment of ovarian cancers usually involves surgery and chemotherapy. The combination of cisplatin and paclitaxel as a chemotherapeutic regimen has improved the survival of ovarian cancer patients. However, the results are not satisfying because of drug resistance developed by cancer cells [2]. The cancer frequently progresses after the treatment and the majority of ovarian cancer patients die as cancer later

\footnotetext{
* Correspondence: chenyc@ab.edu

1 Natural Science Division, Alderson-Broaddus College, Philippi, WV, 26416, USA Full list of author information is available at the end of the article
}

relapses [3]. Therefore, it is important to identify new approaches for the treatment of ovarian cancer.

Flavonoids are polyphenolic natural compounds which are present in a wide variety of fruits and vegetables [4] and are protective against some forms of cancer [5]. It has been reported that dietary flavonoids reduce the risks of humans to cardiovascular disease [6], prostate cancer [7], colorectal cancer [8], and renal cancer [4]. Flavonoids were also reported to inhibit cell growth and proliferation [9] and induce cell toxicity [10] in cancer cells.

Cisplatin (cis-diamminedichloroplatinum(II)) is commonly used in the treatment of various cancers. Cisplatin is activate inside the cell and reacts with guanine residues in DNA. The binding of cisplatin to DNA changes the 
secondary structure of DNA and consequently the metabolism of the cell. The exact mechanism by which cisplatin influences the metabolism of the cell and consequently cell growth is unclear [11].

Several genes have been reported to potentially play a role in cisplatin resistance. The $\mathrm{ABCC} 1, \mathrm{ABCC}$, and $A B C C 6$ genes are members of the $A B C C$ family of membrane transport proteins. These genes have been implicated in drug resistance of a variety of anticancer drugs including platinum based drugs such as cisplatin. Inhibition of these genes is ideal to reduce the efflux of anticancer drugs out of the cell [12]. The NFKB1 gene is a subunit of the NFKB gene, an important regulator of genes controlling a variety of cell survival process including proliferation and apoptosis. Activation of the NFkB gene has been implicated in many human cancers [13]. The genes cMyc and CDKN1A are also important regulators of cell proliferation and apoptosis. However, their role in cisplatin resistance is unclear.

In this study, we investigated the sensitization effects of eight flavonoids (luteolin, genistein, quercetin, kaempferol, taxifolin, rutin hydrate, naringin, and apigenin), and two forms of vitamin $\mathrm{E}$ (tocopherol and tocopherol succinate) on the cisplatin induced killing of cells in the ovarian cancer cell line OVCAR-3. To measure the sensitization effect we used a novel statistical model to distinguish between true sensitization of the cells to cisplatin and the additive effect of the combined toxicity of the sensitization chemical and cisplatin. For any chemicals that showed a sensitization effect we further measured the effect of the cisplatin-chemical combination on the expression of $\mathrm{ABCC} 1, \mathrm{ABCC} 5, \mathrm{ABCC6}, \mathrm{NFkB} 1, \mathrm{cMyc}$ and CDKN1A genes.

\section{Results}

Kaempferol synergistically enhances cisplatin's effect on inhibiting proliferation of OVCAR-3 cancer cells

All 10 chemicals, including 8 flavonoids and $2 \alpha$-tocopherols, were tested at $20-\mu \mathrm{M}$ concentration for their additive or synergistic effects with cisplatin on OVCAR-3 cancer cells. As shown in Figure 1, OVCAR-3 cancer cells are relatively resistant to cisplatin treatment, remaining 88.1-95.3\% (or 1.945-1.979 when logged) viability at 80$\mu \mathrm{M}$ cisplatin concentration. The effects of test chemicals alone (at 20- $\mu \mathrm{M}$ ) vary from no effect (99\% for taxifolin) to moderate effect (67\% for rutin hydrate). With the exception of taxifolin, co-treatment with cisplatin and test chemicals was more effective inhibiting cancer cell proliferation than cisplatin alone, although the majority of these combined effects are additive ( $p>0.05$ for coefficients of Cisplatin*Drug, Table 1). However, for kaempferol and $\alpha$-tocopherol succinate, the resistance to cisplatin in OVCAR-3 cells was reduced, with the cell viability down-regulated to $68.4 \%$ (1.835 when logged) and
$71.3 \%$ (1.853 when logged), respectively. The slope of cisplatin treatment, by linear regression analysis, is changed from -0.012 to -0.070 by co-treatment with $20-\mu \mathrm{M}$ kaempferol, and from -0.019 to -0.051 by co-treatment with $20-\mu \mathrm{M} \alpha$-tocopherol succinate, demonstrating a significant sensitization ( $\mathrm{p}=0.001$ for kaempferol and 0.015 for $\alpha$-tocopherol succinate). The goodness of fit $\left(\mathrm{R}^{2}=0.901\right.$ for kaempferol and 0.891 for $\alpha$-tocopherol succinate) in these models suggests a successful regression on logged viability data with kaempferol and $\alpha$-tocopherol succinate co-treatments (Table 1 ).

\section{Kaempferol enhances cisplatin's effect on gene transcription for ABCC6, cMyc and CDKN1A in OVCAR-3 cancer cells}

Because kaempferol sensitizes OVCAR-3 cancer cells' response to cisplatin treatment, the effect on gene expression by cisplatin and/or kaempferol was further evaluated by analyzing mRNA levels of $\mathrm{ABCC} 1, \mathrm{ABCC}$, ABCC6, NFKB1, cMyc and CDKN1A genes. As shown in Figure 2, cisplatin treatment, with or without kaempferol, does not alter mRNA levels significantly for ABCC1, $\mathrm{ABCC}$, and $\mathrm{NF}_{\kappa} \mathrm{B} 1$ genes. However, cisplatin decreased ABCC6 and cMyc mRNA levels in a dose-dependent manner, with a remaining mRNA level of about $58 \%$ at 80- $\mu \mathrm{M}$ concentration $(\mathrm{p}<0.05)$. Kaempferol treatment also inhibited ABCC6 and cMyc genes transcription down to $68 \%$ ( $\mathrm{p}<0.01)$. Combination of kaempferol with $40-\mu \mathrm{M}$ cisplatin further inhibited ABCC6 and cMyc genes mRNA levels down to $65 \%(\mathrm{p}<0.05)$, and with 80 $\mu \mathrm{M}$ cisplatin leads to the lowest mRNA level of $55 \%$ for $\mathrm{cMyc}(\mathrm{p}<0.01)$, although no enhancement is observed for $\mathrm{ABCC} 6$ gene at $80-\mu \mathrm{M}$ cisplatin concentration. For the CDKN1A gene, cisplatin increased mRNA levels dosedependently, reaching $818.7 \%$ at $80-\mu \mathrm{M}$ concentration (p $<0.05$ ), while kaempferol failed to increase CDKN1A mRNA level significantly $(\mathrm{p}=0.891)$. However, combination of the two chemicals brings the CDKN1A mRNA level up to $1064.7 \%(\mathrm{p}<0.01)$. Due to the known regulation of the CDKN1A gene expression by cMyc, the relationship between the two genes was further examined. The mRNA levels of CDKN1A were plotted against cMyc in a linear scale and a linear relationship was observed between cMyc and CDKN1A mRNA levels, regardless of kaempferol treatment (Figure 3). The two sets of data were pooled for correlation analysis, and the Pearson correlation coefficient is -0.649 , demonstrating a strong negative association $(\mathrm{p}<0.01)$.

\section{Kaempferol promotes apoptosis in OVCAR-3 cancer cells treated with cisplatin}

Cisplatin and kaempferol were also tested for their effects in inducing apoptosis in OVCAR-3 cancer cells. Caspase3 levels in OVCAR-3 cells range from $5-13 \mathrm{pg} / \mu \mathrm{g}$-Total 


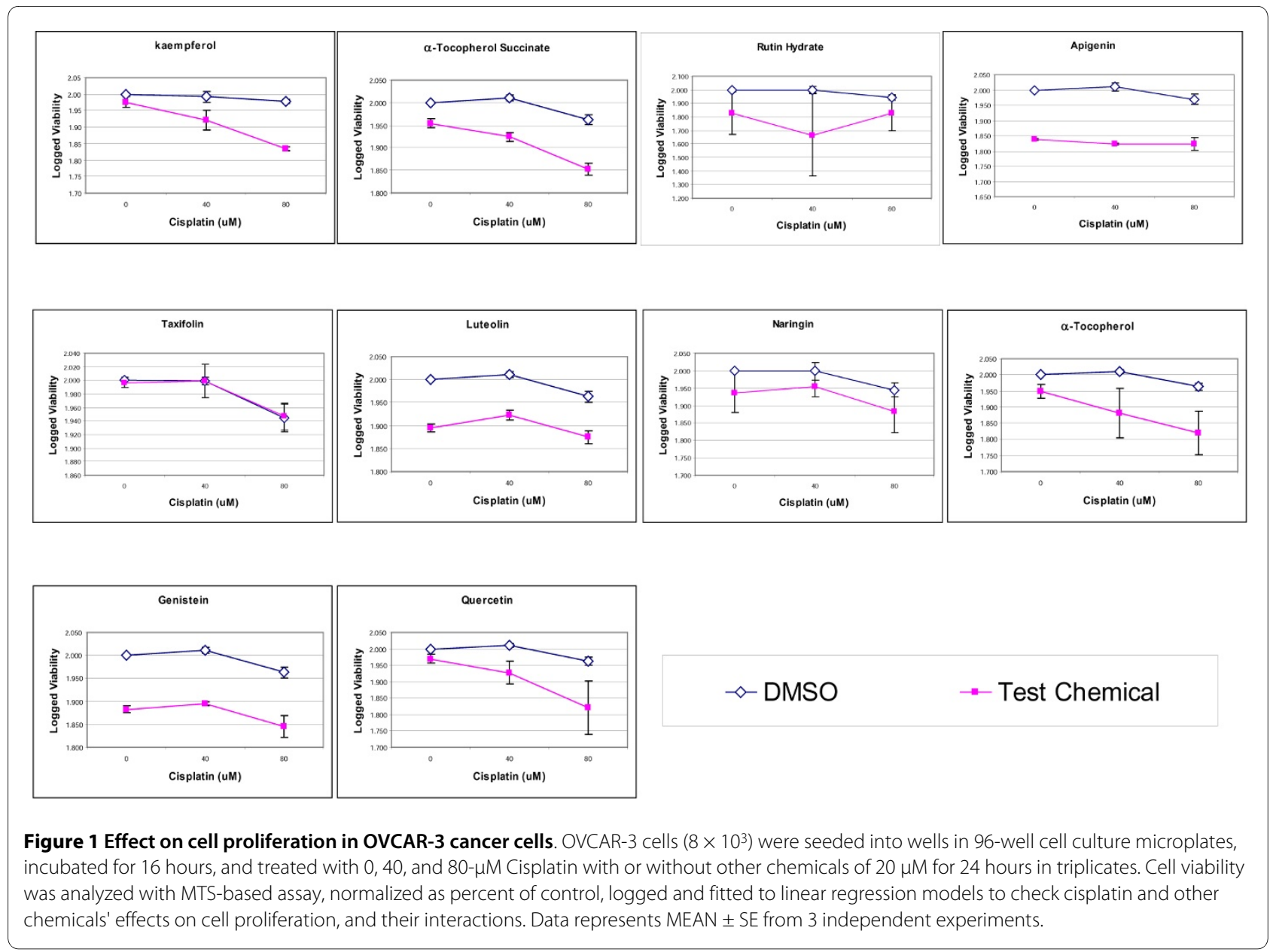

Protein (TP), but showed considerable inter-experiment variances. Caspase-3 levels were expressed as percent of control within each experiment and plotted in logarithmic scale for linear regression analysis. As shown in Figure 4 , cisplatin treatment alone, up to $80 \mu \mathrm{M}$, does not cause any noticeable changes in caspase- 3 levels as compared to the 7.4 pg/ $\mathrm{\mu g}$-TP in control $(\mathrm{p}>0.70)$, while a $20-\mu \mathrm{M}$ kaempferol treatment raised caspase-3 levels to $8.2 \mathrm{pg} / \mu \mathrm{g}$-TP. More importantly, when combined with kaempferol treatment, cisplatin begins to have a dosedependent effect in inducing caspase-3 levels, a significant sensitization proven by linear regression analysis $(\mathrm{p}$ $<0.05$ for coefficient of Cisplatin*Kaempferol, $\mathrm{R}^{2}=$ $0.905)$. The caspase- 3 level is $8.6 \mathrm{pg} / \mu \mathrm{g}$-TP for cells treated with $40-\mu \mathrm{M}$ cisplatin and $20-\mu \mathrm{M}$ kaempferol $(\mathrm{p}<$ $0.05)$ and $9.2 \mathrm{pg} / \mu \mathrm{g}$-TP for cells treated with $80-\mu \mathrm{M}$ cisplatin and $20-\mu \mathrm{M}$ kaempferol, significantly higher than that of control.

\section{Discussion}

There are many different chemotherapy agents for treating cancer. One of the most commonly used chemotherapy drugs is cisplatin. Cisplatin is commonly used in cancers of the head, neck, bladder, ovary, and testis. Unfortunately, many cancer cells are resistant to cisplatin treatment or may become resistant with treatment. Currently the only way to overcome acquired resistance to cisplatin in cancer cells is by increasing dosage, which results in higher toxicity in normal body cells [14]. Resistance to cisplatin treatment can be due to lack of the p53 gene [15], by the activation of cell survival genes such as nuclear factor- $\kappa \mathrm{B}$ (NF- $\mathrm{kB})$ [16], and by the reduced cellular concentration of cisplatin [14].

OVCAR-3 cells were found to be resistant to cisplatin treatment with $88.1-95.3 \%$ viability at $80-\mu \mathrm{M}$ cisplatin concentration. Our previous studies found that flavonoids, including kaempferol, inhibit ovarian cancer cell growth and VEGF expression [17]. Some flavonoids are reported to have sensitization effects on cisplatin $[15,18]$. The 10 chemicals screened, varied in their viability suppression from light to moderate. Among the 10 chemicals tested only kaempferol, a flavonoid, and $\alpha$-tocopherol succinate, a vitamin $E$ derivative, significantly sensitized OVCAR-3 cells to cisplatin treatment. With the exception of taxifolin, all of the combined treatments with cisplatin and the test chemical resulted in a more effective 
Table 1: Linear regression to analyze cisplatin and/or compound's effect on OVCAR-3 cell proliferation.

\begin{tabular}{|c|c|c|c|c|c|c|}
\hline \multirow{3}{*}{ R2 } & \multicolumn{2}{|c|}{ Kaempferol } & \multicolumn{2}{|c|}{ a-Tocopherol Succinate } & \multicolumn{2}{|c|}{ Rutin Hydrate } \\
\hline & \multicolumn{2}{|c|}{0.901} & \multicolumn{2}{|c|}{0.891} & \multicolumn{2}{|c|}{0.188} \\
\hline & B & Sig. & B & Sig. & B & Sig. \\
\hline Constant & 2.002 & 0.000 & 2.010 & 0.000 & 2.009 & 0.000 \\
\hline Cisplatin & -0.012 & 0.198 & -0.019 & 0.040 & -0.028 & 0.789 \\
\hline Compound & -0.022 & 0.238 & -0.048 & 0.006 & -0.237 & 0.221 \\
\hline Cispl. $\times$ Comp & -0.058 & 0.001 & -0.032 & 0.015 & 0.029 & 0.844 \\
\hline
\end{tabular}

\begin{tabular}{|c|c|c|c|c|c|c|}
\hline \multirow{3}{*}{$\mathrm{R} 2$} & \multicolumn{2}{|c|}{ Apigenin } & \multicolumn{2}{|c|}{ Taxifolin } & \multicolumn{2}{|c|}{ Luteolin } \\
\hline & \multicolumn{2}{|c|}{0.947} & \multicolumn{2}{|c|}{0.415} & \multicolumn{2}{|c|}{0.841} \\
\hline & B & Sig. & B & Sig. & B & Sig. \\
\hline Constant & 2.008 & 0.000 & 2.009 & 0.000 & 2.010 & 0.000 \\
\hline Cisplatin & -0.015 & 0.119 & -0.028 & 0.035 & -0.019 & 0.076 \\
\hline Compound & -0.173 & 0.000 & -0.003 & 0.902 & -0.102 & 0.000 \\
\hline Cispl. × Comp. & 0.0080 & 0.571 & 0.003 & 0.884 & 0.008 & 0.548 \\
\hline
\end{tabular}

\begin{tabular}{|c|c|c|c|c|c|c|}
\hline \multirow{3}{*}{$\mathrm{R} 2$} & \multicolumn{2}{|c|}{ Naringin } & \multicolumn{2}{|c|}{ a-Tocopherol } & \multicolumn{2}{|c|}{ Genistein } \\
\hline & \multicolumn{2}{|c|}{0.296} & \multicolumn{2}{|c|}{0.541} & \multicolumn{2}{|c|}{0.885} \\
\hline & B & Sig. & B & Sig. & B & Sig. \\
\hline Constant & 2.009 & 0.000 & 2.010 & 0.000 & 2.010 & 0.000 \\
\hline Cisplatin & -0.028 & 0.306 & -0.019 & 0.521 & -0.019 & 0.086 \\
\hline Compound & -0.058 & 0.243 & -0.062 & 0.253 & -0.117 & 0.000 \\
\hline Cispl. $\times$ Comp & 0.001 & 0.989 & -0.046 & 0.269 & 0.0001 & 0.994 \\
\hline
\end{tabular}

\begin{tabular}{lcc}
\hline & \multicolumn{3}{c}{ Quercetin } \\
\hline R2 & \multicolumn{3}{c}{0.567} & \\
& B & Sig. \\
Constant & 2.010 & 0.000 \\
Cisplatin & -0.019 & 0.467 \\
Compound & -0.029 & 0.533 \\
Cispl. $\times$ Comp. & -0.056 & 0.134 \\
\hline
\end{tabular}

Data from 3 independent experiments were modeled as (Viability = Constant + Cisplatin + Compound + Cisplatin* Compound) to analyze effects of Cisplatin, Compound, and Cisplatin-Compound interactions. Tabulated are standardized coefficients (B) with corresponding $p$ values (Sig.) for each model. The goodness of fit, $\mathrm{R}^{2}$, is also listed for each model. 


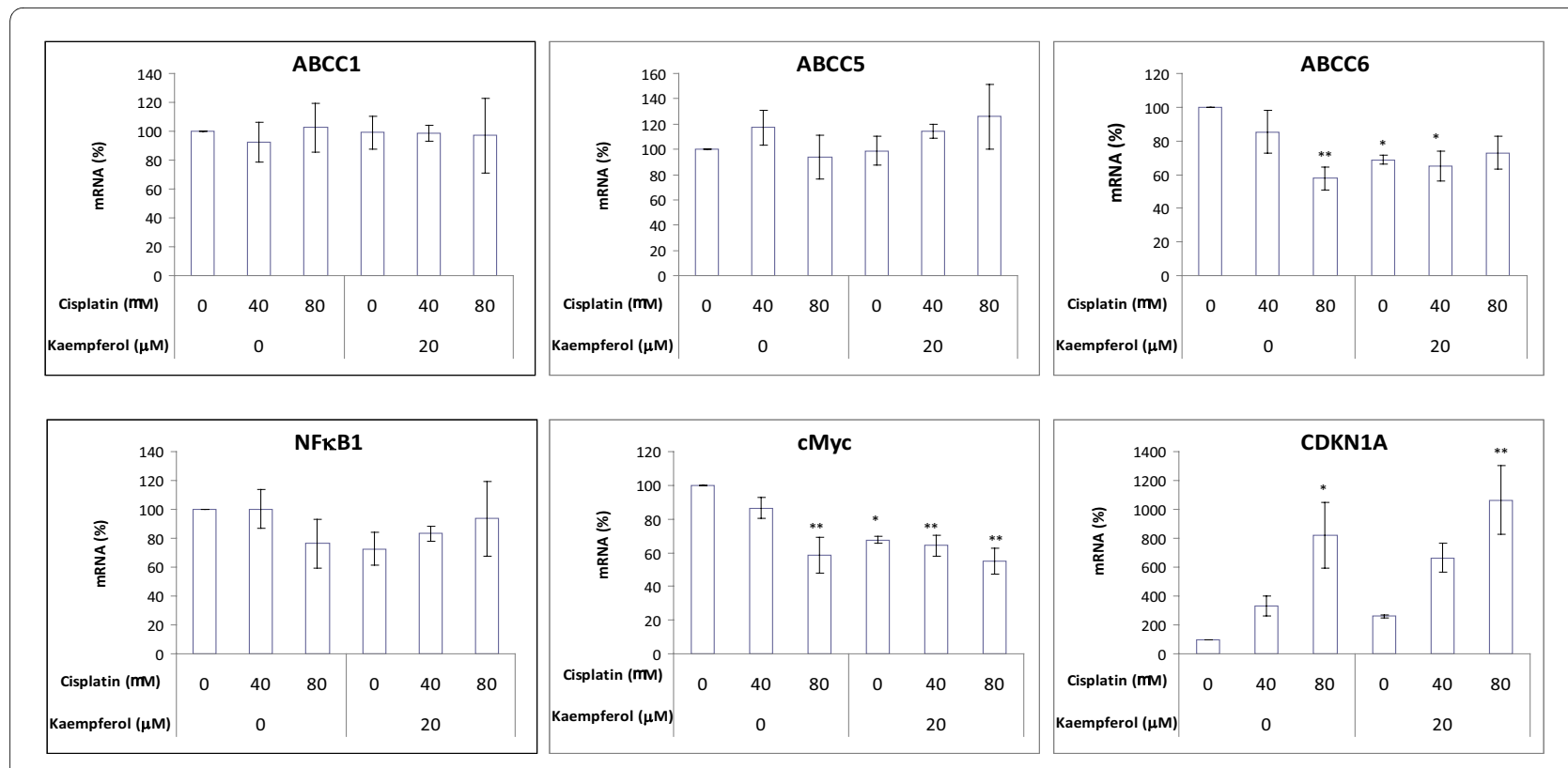

Figure 2 Kaempferol and/or cisplatin's effect on ABCC1, ABCC5, ABCC6, NFKB1, cMyc and CDKN1A mRNA levels. OVCAR-3 cells $\left(5 \times 10^{5}\right)$ were seeded in 60-mm cell culture dishes and incubated for 16 hours before chemical treatment $(0,40$, and 80 - $\mu \mathrm{M}$ cisplatin with or without 20- $\mu \mathrm{M}$ kaempferol) for another 24 hours. RNA was extracted with TRIzol Reagent and quantitated by qRT-PCR as described in Materials and Methods. Gene mRNA levels were adjusted by GAPDH and expressed as percent of control. Data represents MEAN \pm SE from 3 independent experiments. ${ }^{*} p<0.05$ as compared to control by ANOVA Dunnett $t$ test. ${ }^{* *} p<0.01$ as compared to control by ANOVA Dunnett $t$ test.

treatment. However, all of these effects were additive except for kaempferol and $\alpha$-tocopherol succinate.

To gain an insight into the mechanism of kaempferol sensitization, the mRNA levels of $\mathrm{ABCC} 1, \mathrm{ABCC}$, $\mathrm{ABCC6}, \mathrm{NF} \mathrm{B} 1, \mathrm{cMyc}$ and $\mathrm{CDKN1A}$ genes were analyzed by qPCR. The levels of $A B C C 1, A B C C 5$, or NFKB1 were not influenced by cisplatin or kaempferol. With the addition of kaempferol, cisplatin treatment significantly inhibited ABCC6 and cMyc mRNA levels. Since ABCC6 is a membrane transport protein important in the reduction of intracellular accumulation of cisplatin [12], the reduced amount of ABCC6 by kaempferol prevents the removal of cisplatin from the cell leading to the killing of the cancer cell by cisplatin.

Another mechanism of sensitization of cisplatin by kaempferol is through down regulating of $\mathrm{cMyc}$ and up regulation of CDKN1A. The proto-oncogene cMyc is highly expressed in proliferating cells and is commonly activated in human cancers [19]. cMyc is known to down regulate the CDKN1A gene and our study showed a strong negative association between the two (Pearson correlation coefficient, $-0.649, \mathrm{p}<0.01$ ). The up regulation of CDKN1A usually leads to the apoptosis of the cancer cells [20]. Our apoptosis assay showed that cisplatin alone does not induce apoptosis of the ovarian cancer cells. The addition of $20 \mu \mathrm{M}$ kaempferol to the cisplatin treatment induces the apoptosis of the cancer cells. Therefore, kae- mpferol enhances the effect of cisplatin through down regulation of cMyc in promoting apoptosis of ovarian cancer cells.

\section{Conclusions}

Our work found that kaempferol works synergistically with cisplatin in inhibiting ovarian cancer cell viability, and their inhibition on cell viabilities was induced through inhibiting ABCC6 and cMyc gene transcription. Apoptosis assay showed the addition of $20 \mu \mathrm{M}$ kaempferol to the cisplatin treatment induces the apoptosis of the cancer cells. Therefore, kaempferol enhances the effect of cisplatin through down regulation of cMyc in promoting apoptosis of ovarian cancer cells. As a dietary component, kaempferol sensitizes ovarian cancer cells to cisplatin treatment and deserves further studies for possible applications in chemotherapy of ovarian cancers.

\section{Methods \\ Chemicals}

All 11 chemicals, including cisplatin, $2 \alpha$-tocopherols, and 8 flavonoids were obtained from Sigma (St. Louis, $\mathrm{MO})$. Chemicals were dissolved in DMSO to form a 20$\mathrm{mM}$ stock solution which were stored at $-20^{\circ} \mathrm{C}$. For cell treatment, DMSO concentrations were controlled constant through various concentration and chemical combinations. 


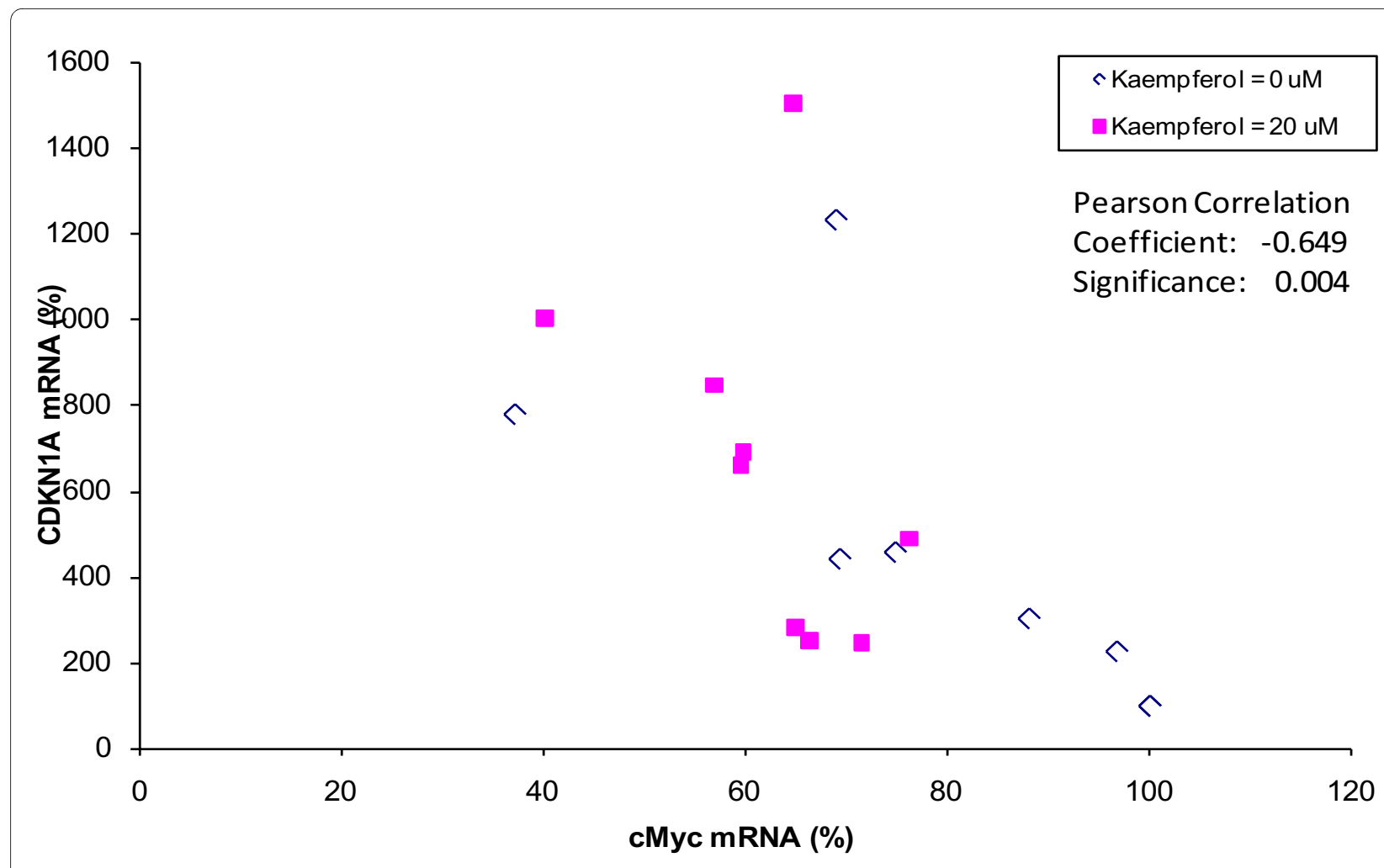

Figure 3 Negative correlation between cMyc and CDKN1A gene mRNA levels. The mRNA levels of CDKN1A and cMyc from 3 independent experiments were expressed as percent and plotted against each other for Pearson Correlation analysis. A strong negative association exits for CDKN1 A and cMyc genes (as regulated by cisplatin treatment) regardless of kaempferol treatment.

\section{Cell Culture}

The human ovarian cancer cell line OVCAR-3 was obtained from American Type Culture Collection (Manassas, VA). Cells were cultured in RPMI 1640 medium supplemented with $4 \mu \mathrm{mol} / \mathrm{mL}$ glutamine, 100 units/mL penicillin, $100 \mu \mathrm{g} / \mathrm{mL}$ streptomycin (VWR, West Chester, PA), and 10\% US-qualified fetal bovine serum (Invitrogen, Grand Island, NY) in a humidified incubator with $5 \% \mathrm{CO}_{2}$ at $37^{\circ} \mathrm{C}$.

\section{Cell Proliferation Assay}

Chemical effects on OVCAR-3 cell proliferation were colorimetrically determined with a "CellTiter $96^{\circ}$ Aqueous One Solution Cell Proliferation Assay" kit from Promega (Madison, WI). OVCAR-3 cells $\left(8 \times 10^{3}\right)$ were seeded into wells in 96-well cell culture microplates and incubated for 16 hours. Chemical treatments $(0,40$, and 80- $\mu \mathrm{M}$ Cisplatin with other chemicals of 0 , or $20-\mu \mathrm{M})$ were then applied in triplicates for another 24 hours. After removal of medium, $100 \mu \mathrm{L}$ freshly-prepared Aqueous One Solution (MTS tetrazolium compound) was added to each well, incubated at $37^{\circ} \mathrm{C}$ for 2 hours, and optical density (OD) measured at $490 \mathrm{~nm}$ with a microplate reader (BioRad, Hercules, CA). A linear standard curve was gener- ated by seeding different numbers of cells $\left(0-1 \times 10^{4}\right)$ at the beginning and used to quantify chemical-treated cells' viability. Cell viability was expressed as percent of control (0- $\mu \mathrm{M}$ cisplatin and $0-\mu \mathrm{M}$ other chemicals), and averaged from replicates. Data from 3 independent experiments were pooled for statistical analysis.

\section{Quantification of mRNA levels for ABCC1, ABCC5, ABCC6, NFKB1, cMyc and CDKN1A genes}

Effect on transcription of the 6 genes' were determined by quantitative reverse-transcription Polymerase Chain Reaction (qRT-PCR). OVCAR-3 cells $\left(5 \times 10^{5}\right)$ were seeded in $60-\mathrm{mm}$ cell culture dishes and incubated for 16 hours before chemical treatment $(0,40$, and $80-\mu \mathrm{M}$ cisplatin with or without 20- $\mu \mathrm{M}$ kaempferol) for another 24 hours. Cells were washed twice with PBS (Phosphate Buffered Saline), and RNA was extracted with TRIzol Reagent (Invitrogen, Grand Island, NY). RNA was resuspended in DEPC (diethyl pyrocarbonate)-treated water and introduced to reverse transcription with oligo-dT and AMV Reverse Transcriptase from Promega (Madison, WI). Real-time PCR was deployed to amplify cDNA for the 6 genes with RT2 ${ }^{2}$ SYBR Green qPCR Master Mix (SuperArray Bioscience, Frederick, MD) and a Chromo4 


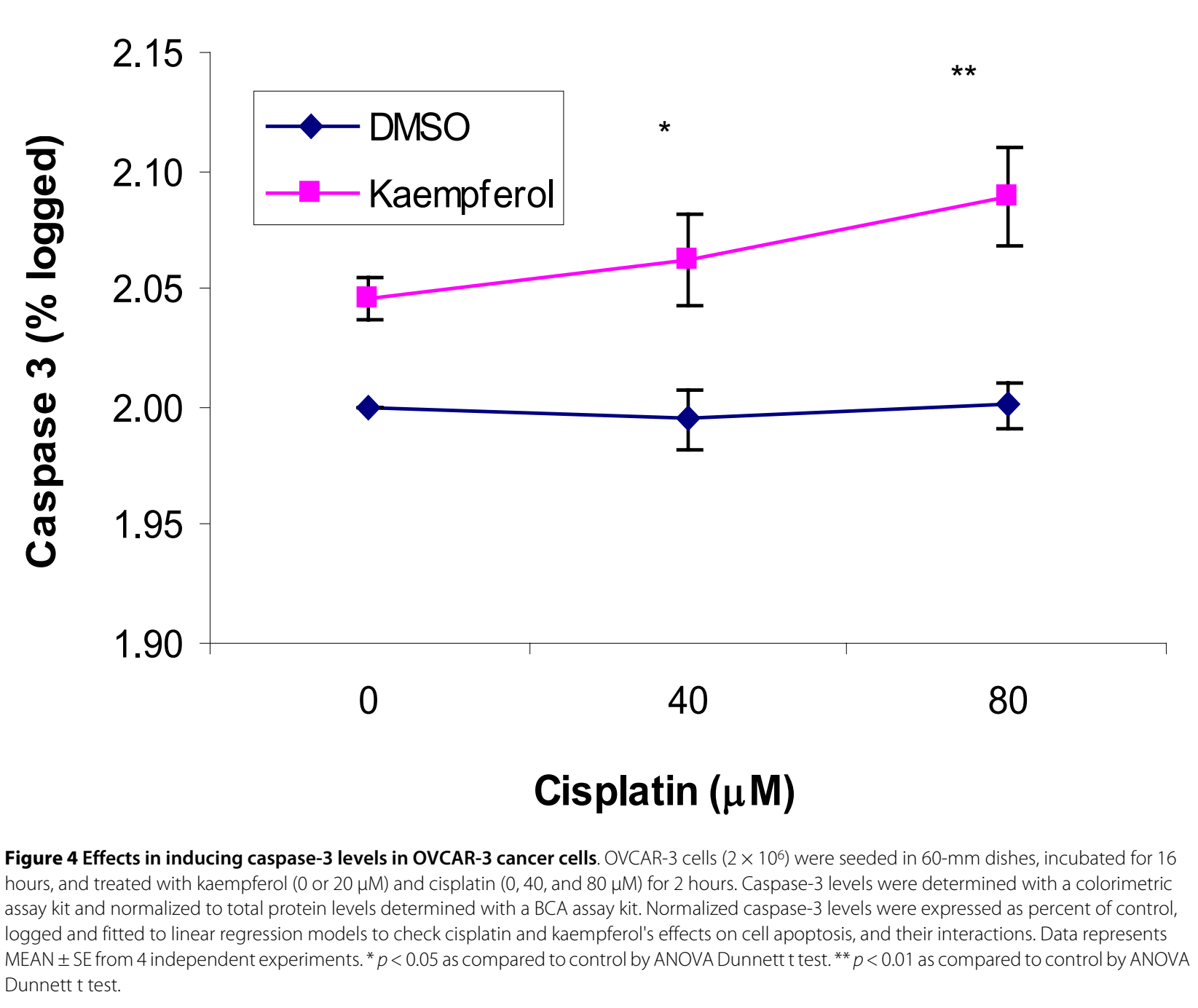

real-time detector coupled to a DNA Engine thermal cycler (Bia-Rad, Hercules, CA). Primers for CDKN1A were designed from the Primer3 website http:// frodo.wi.mit.edu/primer3/ to amplify both transcript variants, and primers for other genes were chosen from the PrimerBank website http://pga.mgh.harvard.edu/ primerbank/ (Table 2). The PCR program was set as follow: $95^{\circ} \mathrm{C} 10^{\prime} ;\left(95^{\circ} \mathrm{C} 20^{\prime \prime}, 58^{\circ} \mathrm{C} 45^{\prime \prime}, 72^{\circ} \mathrm{C} 20^{\prime \prime}, 77^{\circ} \mathrm{C} 1\right.$ ", read plate) $\times 50 ; 72^{\circ} \mathrm{C} 5^{\prime} ; 58^{\circ} \mathrm{C} 1^{\prime}$; melting curve $\left(65^{\circ} \mathrm{C}-95^{\circ} \mathrm{C}\right.$ by $0.5^{\circ} \mathrm{C}$ increments). A standard curve was generated from series dilutions of PCR products to monitor amplification efficiency, and to relatively quantify samples for every gene. RNA samples without reverse transcription served as non-reverse-transcription (-RT) controls, and melting curves were checked for uniform amplification. In processing amplification curves, baselines were set as average levels through cycle 2-12, and threshold values was set as 0.01 . Gene expression levels, as relatively quantified by individual standard curves, were further adjusted by
GAPDH (Glyceraldehyde 3-phosphate dehydrogenase) levels, and expressed as percent of control $(0-\mu \mathrm{M}$ cisplatin and $0-\mu \mathrm{M}$ kaempferol). Data from 3 independent experiments were pooled for statistical analysis.

\section{Apoptosis Assay}

Cell apoptosis was determined by measuring caspase-3 levels with a Caspase-3 Colorimetric Assay Kit (R\&D Systems, Minneapolis, MN) and total protein levels with a BCA (bicinchoninic acid) Protein Assay Kit (Pierce Biotechnology, Rockford, IL). Cells $\left(2 \times 10^{6}\right)$ were seeded in $60-\mathrm{mm}$ dishes and incubated 16 hours before being treated with kaempferol $(0$ or $20 \mu \mathrm{M})$ and cisplatin $(0,40$, and $80 \mu \mathrm{M}$ ) for 2 hours. After 3 washes with cold PBS, cells were harvested in lysis buffer, and cell lysates were collected for caspase- 3 assay and for the BCA assay as per instructions. Standard curves were generated by serial dilution of recombinant human caspase-3 (R\&D Systems) and albumin standards $(2 \mathrm{mg} / \mathrm{mL})$, and caspase-3 levels 
Table 2: Primer sequences for genes analyzed.

\begin{tabular}{|c|c|c|c|}
\hline Gene & GenBank Accession & Primers & Amplicon size \\
\hline \multirow[t]{2}{*}{ GAPDH } & NM 002046 & CAT GAG AAG TAT GAC AAC AGC CT & 113 \\
\hline & & AGT CCT TCC ACG ATA CCA AAG T & \\
\hline \multirow[t]{2}{*}{ ABCC1 } & NM 004996 & CCA GTG GGG ATC GGA CAG A & 124 \\
\hline & & AGG GGA TCA TCG AAG AGG TAA AT & \\
\hline \multirow[t]{2}{*}{ ABCC5 } & NM 005688 & CCA GGG TCC TGA TTC GGG A & 122 \\
\hline & & СTC CTG CCC TTT ATT GTA GGC & \\
\hline \multirow[t]{2}{*}{ ABCC6 } & NM 001171 & AGC CAG CTA CTC GTC TGT CT & 108 \\
\hline & & CGA GCA TTG TTC TGA GCC A & \\
\hline \multirow[t]{2}{*}{ NFkB1 } & NM 003998 & ATT TGA AAC ACT GGA AGC ACG A & 145 \\
\hline & & GCG GAT TAG CTC गाT TाC CCG & \\
\hline \multirow[t]{2}{*}{ cMyc } & NM 002467 & TCG GAA GGA CTA TCC TGC TG & 133 \\
\hline & & GTG TGT TCG CCT CTT GAC ATT & \\
\hline \multirow[t]{2}{*}{ CDKN1A } & NM 000389 & TTA GCA GCG GAA CAA GGA GT & 226 \\
\hline & & AGC CGA GAG AAA ACA GTC CA & \\
\hline
\end{tabular}

were normalized to total protein levels for each sample. Normalized caspase- 3 levels were expressed as percent of control and logged for linear regression analysis. A total of 4 independent experiments were performed for statistical analysis.

\section{Statistical Analysis}

All data were normalized as percent of control within each experiment and data from several independent experiments were pooled to represent three biological replicates. For mRNA levels and caspase-3 levels, treatment groups with various concentrations of cisplatin and/or kaempferol were compared against control by ANOVA with Dunnett $t$ multiple comparisons in SPSS 15.0 software (SPSS Inc, Chicago, IL). For detection of interactions between cisplatin and compounds, cell viability levels and caspase- 3 levels (at logarithmic scale) were plotted against cisplatin (coded as 0, 1, 2 to represent 0,40 , and $80 \mu \mathrm{M}$ cisplatin, respectively) with or without $20-\mu \mathrm{M}$ test chemical (coded as 0,1 ) for linear regression analysis in SPSS 15.0 software. Cisplatin, compound, and the product between cisplatin and compound were entered as 3 predictors for linear regression analysis to examine the effects of cisplatin, compound, and cisplatin-compound interaction, respectively $(\mathrm{Y}=$ Constant + Cisplatin + Compound + Cisplatin ${ }^{*}$ Compound). An additive effect between cisplatin and compound will give two lines nearly parallel, while an interaction will have unparallel lines and a significant coefficient for the product predictor: Cisplatin*Compound. A sensitization effect can be seen when there is an interaction between cisplatin and compound and the effect of cisplatin is amplified by co-treatment with compound: two lines that depart from each other when moving toward higher cisplatin concentrations. The relationship between cMyc and CDKN1A genes' mRNA levles was evaluated by Pears' Correlation Analysis in SPSS software.

\section{Declaration of Competing interests}

The authors declare that they have no competing interests.

\section{Abbreviations}

VEGF: vascular endothelial growth factor; CDKN1A: Cyclin-dependent kinase inhibitor $1 \mathrm{~A}$.

\section{Authors' contributions}

$\mathrm{HL}$ carried out the majority of experimental work. YC drafted the manuscript. All authors participated experimental design, read and approved the final manuscript.

\section{Acknowledgements}

This research was supported by grant P20 RR16477 from the National Center for Research Resources awarded to the West Virginia IDeA Network for Biomedical Research Excellence.

\section{Author Details}

1Natural Science Division, Alderson-Broaddus College, Philippi, WV, 26416, USA , 2Mary Babb Randolph Cancer Center, Department of Microbiology, Immunology, and Cell Biology, West Virginia University, Morgantown, WV, USA and ${ }^{3}$ Department of Pharmacology, Physiology and Toxicology, Joan C. Edwards School of Medicine, Marshall University, Huntington, WV, USA

Received: 29 January 2010 Accepted: 11 May 2010

Published: 11 May 2010

\section{References}

1. Jemal A, Tiwari RC, Murray T, Ghafoor A, Samuels A, Ward E, Feuer EJ, Thun MJ: Cancer Statistics, 2004. CA Cancer J Clin 2004, 54:8-29.

2. Perez RP, Godwin AK, Hamilton TC, Ozols RF: Ovarian cancer biology. Semin Oncol 1991, 18:186-204. 
3. McGuire WP, Hoskins WJ, Brady MF, Kucera PR, Partridge EE, Look KY, Clarke-Pearson DL, Davidson M: Cyclophosphamide and cisplatin compared with paclitaxel and cisplatin in patients with stage III and stage IV ovarian cancer. N Engl J Med 1996, 334:1-6.

4. Bosetti C, Rossi M, McLaughlin JK, Negri E, Talamini R, Lagiou P, Montella M, Ramazzotti V, Franceschi S, LaVecchia C: Flavonoids and the risk of renal cell carcinoma. Cancer Epidemiol Biomarkers Prev 16:98-101.

5. Gonzalez CA, Riboli E: Diet and cancer prevention: where we are, where we are going. Nutr Cancer 2006, 56:225-31.

6. Mink PJ, Scrafford CG, Barraj LM, Harnack L, Hong CP, Nettleton JA, Jacobs DR Jr: Flavonoid intake and cardiovascular disease mortality: a prospective study in postmenopausal women. Am J Clin Nutr 2007, 85:895-909.

7. Bosetti C, Bravi F, Talamini R, Parpinel M, Gnagnarella P, Negri E, Montella $M$, Lagiou P, Franceschi S, La Vecchia C: Flavonoids and prostate cancer risk: a study in Italy. Nutr Cancer 2006, 56:123-7.

8. Theodoratou E, Kyle J, Cetnarskyj R, Farrington SM, Tenesa A, Barnetson R, Porteous M, Dunlop M, Campbell H: Dietary flavonoids and the risk of colorectal cancer. Cancer Epidemiol Biomarkers Prev 2007, 16:684-93.

9. Adhami VM, Malik A, Zaman N, Sarfaraz S, Siddiqui IA, Syed DN, Afaq F, Pasha FS, Saleem M, Mukhtar H: Combined inhibitory effects of green tea polyphenols and selective cyclooxygenase- 2 inhibitors on the growth of human prostate cancer cells both in vitro and in vivo. Clin Cancer Res 2007, 13:1611-9.

10. Plochmann K, Korte G, Koutsilieri E, Richling E, Riederer P, Rethwilm A, Schreier P, Scheller C: Structure-activity relationships of flavonoidinduced cytotoxicity on human leukemia cells. Arch Biochem Biophys 2007, 460:1-9.

11. Brabec V: Chemistry and structural biology of 1,2-intrastrand adducts of cisplatin. In Platinum Based Drugs in Cancer Therapy 1st edition. Edited by: Kelladn LR, Farell NP. Totowa, NJ: Humana Press Inc; 2000:37-61.

12. Zhou SF, Wang LL, Di YM, Xue CC, Duan W, Li CG, Li Y: Substrates and inhibitors of human multidrug resistance associated proteins and the implications in drug development. Curr Med Chem 2008, 15:1987-2039.

13. Shukla S, Gupta S: Suppression of Constitutive and Tumor Necrosis Factor a-Induced Nuclear Factor (NF)-kB Activation and Induction of Apoptosis by Apigenin in Human Prostate Carcinoma PC-3 Cells: Correlation with Down-Regulation of NF-KB-Responsive Genes. Clinical Cancer Research 2004, 10:3169-78.

14. Isonishi S, Ohkawa K, Tanaka T, Howell SB: Depletion of protein kinase C (PKC) by 12-O-tetradecanolyphorbol-13-acetate (TPA) enhances platinum drug sensitivity in human ovarian carcinoma cells. British $J$ of Cancer 2000, 82:34-38.

15. Shi R, Huang Q, Zhu X, Ong YB, Zhao B, Lu J, Ong CN, Shen HM: Luteolin sensitizes the anticancer effect of cisplatin via c-Jun NH2-terminal kinase-mediated p53 phosphorylation and stabilization. Mol Cancer Ther 2007, 6:1338-47.

16. Banerjee S, Zhang Y, Wang Z, Che M, Chiao PJ, Abbruzzese JL, Sarkar FH: In vitro and in vivo molecular evidence of genistein action in augmenting the efficacy of cisplatin in pancreatic cancer. Int J Cancer 2007 120:906-17.

17. Luo H, Jiang B, King SM, Chen YC: Inhibition of Cell Growth and VEGF Expression in Ovarian Cancer Cells by Flavonoids. Nutrition and Cancer 2008, 60(6):800-809.

18. Sharma H, Sen S, Singh N: Molecular pathways in the chemosensitization of cisplatin by quercentin in human head and neck cancer. Cancer Biol Ther 2005, 4:949-55.

19. Jung P, Menssen A, Mayr D, Hermeking H: AP4 encodes a c-MYCinducible repressor of p21. Proc Natl Acad Sci USA 2008, 105(39):15046-51.

20. Seoane J, Le HV, Massagué J: Myc suppression of the p21 (Cip1) Cdk inhibitor influences the outcome of the p53 response to DNA damage. Nature 2002, 419(6908):729-34.

\section{Submit your next manuscript to BioMed Central} and take full advantage of:

- Convenient online submission

- Thorough peer review

- No space constraints or color figure charges

- Immediate publication on acceptance

- Inclusion in PubMed, CAS, Scopus and Google Scholar

- Research which is freely available for redistribution 